\title{
Novel aprotic polar solvents for facile Baylis-Hillman reaction ${ }^{\#}$
}

\author{
Palakodety Radha Krishna,* A Manjuvani, and Empati Raja Sekhar \\ D-206/B, Discovery Laboratory, Organic Chemistry Division-III, \\ Indian Institute of Chemical Technology, Hyderabad-500 007, India \\ E-mail:prkgenius@iict.res.in
}

\section{Dedicated to Dr. A V Rama Rao on his $7^{\text {th }}$ birthday April 2, 2005 \\ (received 01 Sep 04; accepted 05 Nov 04; published on the web 20 Nov 04)}

\begin{abstract}
Novel aprotic polar solvents are selected for use towards a facile Baylis-Hillman reaction catalyzed by the standard base (DABCO) at room temperature so that less reactive aldehydes and a broad spectrum of activated olefins (including acrylamide) could be coupled under the altered reaction conditions.
\end{abstract}

Keywords: Baylis-Hillman reaction, sulpholane, $N$-methylpyrrolidinone, $N$-methylmorpholine, acryl amide

\section{Introduction}

The Morita-Baylis-Hillman reaction, ${ }^{1}$ since its discovery, has witnessed a renaissance in recent times. ${ }^{2}$ Baylis-Hillman reaction, ${ }^{3}$ as it is commonly known as, is an important carbon-carbon bond forming reaction between activated alkenes and aldehydes in the presence of tertiary amine base catalysts such as DABCO to result in valuable multifunctional products. However, it traditionally suffered from low reactivity and limited substrate scope. Consequently, many research efforts have been directed either to enhance the rate of reaction by increasing the reactivity of aldehydes or use novel catalysts with higher $p K a$ values eg. 3-HQD, ${ }^{4}$ QD-4 ${ }^{5}$ (Figure 1).

\section{Figure 1}

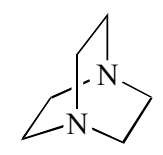

DABCO

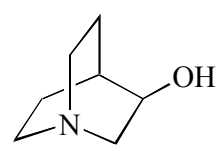

3-Hydroxy -quinuclidine (3-HOD)

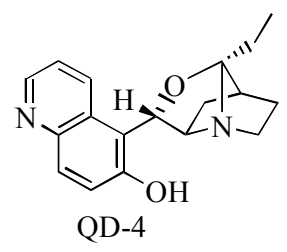


Noteworthy among the many is the use of $3-\mathrm{HQD}^{4}$ in water as solvent to achieve faster reaction times and higher yields. Particularly to bring the less reactive aldehydes like aliphatic aldehydes into the purview of this reaction, dioxane:water ${ }^{6}$ solvent system played a crucial role. Similarly, towards this endeavor, sulpholane ${ }^{7}$ was another important addition from our laboratories. Aprotic polar solvents are expected i) to eliminate the problem of ester hydrolysis (for ethyl/methyl acrylates) thus reducing their excess use, ii) to elevate the $p K a$ of the base used (DABCO in the present study), iii) stabilization of the 'zwitterionic intermediate by chargedipole interactions. ${ }^{4,8}$ In view of the above cited reasons and as a part of our ongoing efforts to extend the scope of Baylis-Hillman reaction ${ }^{9}$ we have undertaken the study on the use of novel aprotic polar solvents for facile Baylis-Hillman reaction (Equation 1). The results are presented herein.

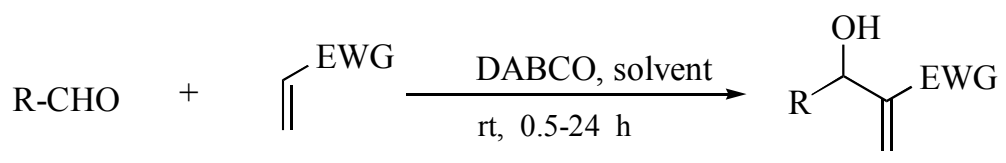

\section{Equation 1}

\section{Results and Discussion}

Commercially available polar aprotic solvents namely; sulpholane, ${ }^{7} \mathrm{~N}$-methylpyrrolidinone, ${ }^{10} \mathrm{~N}$ methylmorpholine ${ }^{11}$ etc were screened for use in Baylis-Hillman reaction as alternate solvents. Initially, the Baylis-Hillman reaction between 4-nitrobenzaldehyde $\mathbf{1}$ and ethyl acrylate a in sulpholane, $N$-methylpyrrolidinone (NMP) and $N$-methylmorpholine (NMM) was carried out to give 1a in the presence of different bases such as DBU, DMAP, urotropine, and DABCO (Table 1) in order to find the appropriate base catalyst compatible with the selected solvents. Consequently, DABCO was found to be the standard base and elected for use in all further reactions. 
Table 1. Baylis-Hillman ractions of 1 and a with different bases is different solvents

\begin{tabular}{|c|c|c|c|c|}
\hline Entry & Base & Solvent & $\begin{array}{l}\text { Time } \\
\text { (h) }\end{array}$ & $\begin{array}{c}\text { Product/ Yield } \\
\%\end{array}$ \\
\hline 1 & $\mathrm{DBU}$ & Sulpholane & 0.5 & 1a, 30 \\
\hline 2 & DMAP & Sulpholane & 6 & $\mathbf{1 a}, 55$ \\
\hline 3 & Urotropine & Sulpholane & 6 & $\mathbf{1 a}, 80$ \\
\hline 4 & $\mathrm{DABCO}$ & Sulpholane & 2 & $\mathbf{1 a}, 96$ \\
\hline 5 & DBU & $N$-methylmorpholine & 4 & $\mathbf{1 a}, 86$ \\
\hline 6 & DMAP & $N$-methyl morpholine & 24 & $\mathbf{1 a}, 70$ \\
\hline 7 & Urotropine & $N$-methyl morpholine & 24 & $\mathbf{1 a}, 50$ \\
\hline 8 & $\mathrm{DABCO}$ & $N$-methyl morpholine & 4 & $\mathbf{1 a}, 91$ \\
\hline 9 & $\mathrm{DBU}$ & $N$-methyl pyrrolidinone & $4-5$ & $\mathbf{1 a}, 75$ \\
\hline 10 & DMAP & $N$-methyl pyrrolidinone & 24 & $\mathbf{1 a}, 80$ \\
\hline 11 & Urotropine & $N$-methyl pyrrolidinone & 24 & $\mathbf{1 a}, 80$ \\
\hline 12 & $\mathrm{DABCO}$ & $N$-methyl pyrrolidinone & 4 & $\mathbf{1 a}, 90$ \\
\hline
\end{tabular}

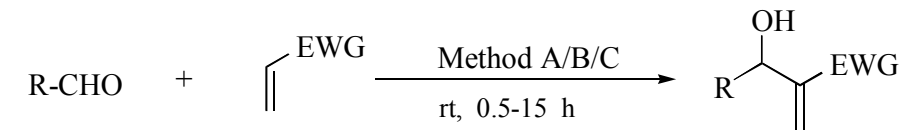

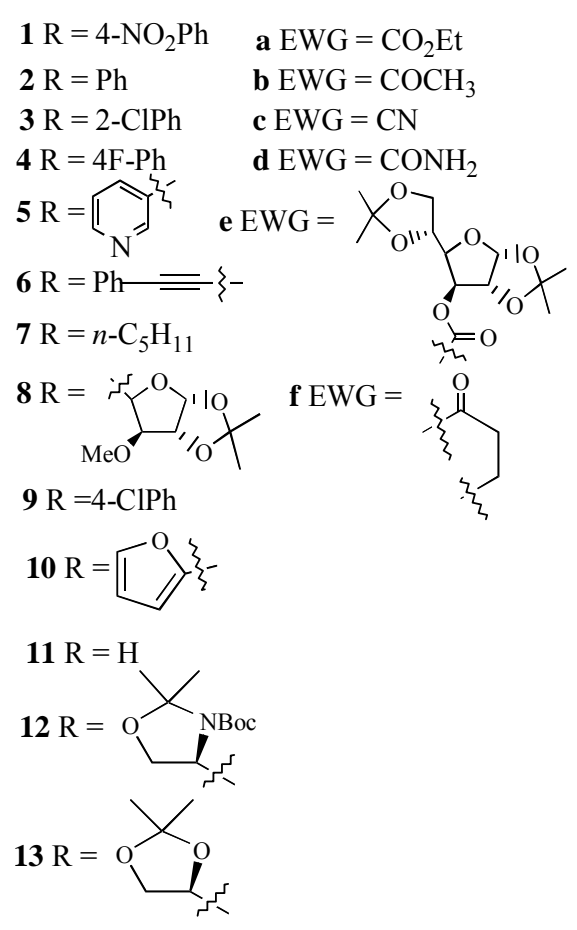

1a $\mathrm{R}=4-\mathrm{NO}_{2} \mathrm{Ph}, \mathrm{EWG}=\mathrm{CO}_{2} \mathrm{Et}$ 1b $\mathrm{R}=4-\mathrm{NO}_{2} \mathrm{Ph}, \mathrm{EWG}=\mathrm{COCH}_{3}$ 1c $\mathrm{R}=4-\mathrm{NO}_{2} \mathrm{Ph}, \mathrm{EWG}=\mathrm{CN}$ 1d $\mathrm{R}=4-\mathrm{NO}_{2} \mathrm{Ph}, \mathrm{EWG}=\mathrm{CONH}_{2}$ 1e $\mathrm{R}=4-\mathrm{NO}_{2} \mathrm{Ph}, \mathrm{EWG}=$ Sugar 1f $\mathrm{R}=4-\mathrm{NO}_{2} \mathrm{Ph}, \mathrm{EWG}=$ Cyclohexenone

2a $\mathrm{R}=\mathrm{Ph}, \mathrm{EWG}=\mathrm{CO}_{2} \mathrm{Et}$

2b $\mathrm{R}=\mathrm{Ph}, \mathrm{EWG}=\mathrm{COCH}_{3}$

2c $\mathrm{R}=\mathrm{Ph}, \mathrm{EWG}=\mathrm{CN}$

2d $\mathrm{R}=\mathrm{Ph}, \mathrm{EWG}=\mathrm{CONH}_{2}$

2f $\mathrm{R}=\mathrm{Ph}, \mathrm{EWG}=$ Cyclohexenone

3a $\mathrm{R}=2-\mathrm{ClPh}, \mathrm{EWG}=\mathrm{CO}_{2} \mathrm{Et}$

4a $\mathrm{R}=4-\mathrm{FPh}, \mathrm{EWG}=\mathrm{CO}_{2} \mathrm{Et}$

5a $\mathrm{R}=3$-Pyridyl, $\mathrm{EWG}=\mathrm{CO}_{2} \mathrm{Et}$

5b $\mathrm{R}=3$-Pyridyl, EWG $=\mathrm{COCH}_{3}$

5c R $=3$-Pyridyl, $\mathrm{EWG}=\mathrm{CN}$

5d R $=3$-Pyridyl, $\mathrm{EWG}=\mathrm{CONH}_{2}$

5f $\mathrm{R}=3$-Pyridyl, EWG $=$ Cyclo-

hexenone 6a $\mathrm{R}=\mathrm{Ph}=\xi-\quad \mathrm{EWG}=\mathrm{CO}_{2} \mathrm{Et}$

6b $\mathrm{R}=\mathrm{Ph}=\left\{-\quad \mathrm{EWG}=\mathrm{COCH}_{3}\right.$

7a R $=n-\mathrm{C}_{5} \mathrm{H}_{11}, \mathrm{EWG}=\mathrm{CO}_{2} \mathrm{Et}$

$7 \mathbf{b} \mathrm{R}=n-\mathrm{C}_{5} \mathrm{H}_{11}, \mathrm{EWG}=\mathrm{COCH}_{3}$

7c $\mathrm{R}=n-\mathrm{C}_{5} \mathrm{H}_{11}, \mathrm{EWG}=\mathrm{CN}$

7d R $=n-\mathrm{C}_{5} \mathrm{H}_{11}, \mathrm{EWG}=\mathrm{CONH}_{2}$

8a $\mathrm{R}=$ Sugar, $\mathrm{EWG}=\mathrm{CO}_{2} \mathrm{Et}$

8b $\mathrm{R}=$ Sugar, $\mathrm{EWG}=\mathrm{COCH}_{3}$

9a $\mathrm{R}=4-\mathrm{ClPh}, \mathrm{EWG}=\mathrm{CO}_{2} \mathrm{Et}$

9d $\mathrm{R}=4-\mathrm{ClPh}, \mathrm{EWG}=\mathrm{CONH}_{2}$

10a $\mathrm{R}=$ Furyl, $\mathrm{EWG}=\mathrm{CO}_{2} \mathrm{Et}$

10d $\mathrm{R}=$ Furyl, $\mathrm{EWG}=\mathrm{CONH}_{2}$

11d $\mathrm{R}=\mathrm{H}, \mathrm{EWG}=\mathrm{CONH}_{2}$

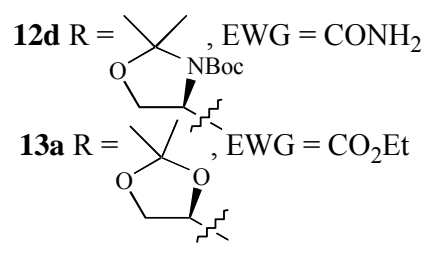

\section{Scheme 1}


Next, a variety of Michael acceptors such as methyl vinyl ketone $\mathbf{b}$, acrylonitrile $\mathbf{c}$, and acrylamide $\mathbf{d}$ were subjected to reaction with 1 in the presence of DABCO $(50 \mathrm{~mol} \%)$ at room temperature to furnish the corresponding adducts $\mathbf{1 b}, \mathbf{1 c}$ and $\mathbf{1 d}$ in good yields (Scheme 1 and Table 2). The less reactive $\mathbf{d}$, which was earlier reported ${ }^{2 b}$ to react either at high pressure (5 kbar) or in aqueous dioxane ${ }^{12}$ as solvent at room temperature, on reaction with $\mathbf{1}$ in sulpholane afforded $1 \mathbf{d}^{7}$ in $84 \%$ yield. Sugar acrylate e also reacted with $\mathbf{1}$ to furnish the corresponding adduct $1 \mathrm{e}^{9 \mathrm{a}}(76 \%)$ under the present reaction conditions.

Likewise to test the versatility of sulpholane, NMP and NMM as compatible solvents for Baylis-Hillman reaction, a variety of aldehydes such benzaldehyde 2, 2- and -4 chlorobenzaldehydes 3 and 9; 4-flourobenzaldehyde 4, heteroaryl aldehydes 5 and 10; acetylenic aldehyde 6, aliphatic aldehydes 7 and 11; and chiral aldehydes 8, 12 and 13 were allowed to react with various Michael acceptors a-d and $\mathrm{f}$ at room temperature to give the adducts 2a-d, 2f, 3a, 4a, 5a-d, 5f, 6a-b, ${ }^{9 \mathrm{c}}$ 7a-d, 8a-b, 9a, 9d, 10a, 10d, 11d, 12d and 13a respectively in good to excellent yields under the specified reaction conditions (see Scheme 1 and Table 2). It is noteworthy to mention that the sugar derived aldehyde $\mathbf{8}$ in sulpholane reacted with $\mathbf{a}$ and $\mathbf{b}$ to give the adducts $\mathbf{8 a}$ and $\mathbf{8 b}$, respectively (entries 25 and 26, Table 2) in short reaction times with moderate diastereoselectivity, unlike in our earlier ${ }^{9 b}$ report. Furthermore, aldehydes such as 2, 3 and 4 reacted with the less reactive alkene a under the present reaction conditions (entries 7, 12 and 13, Table 2). Indeed, the rate of reaction of aldehydes $\mathbf{3}$ and $\mathbf{4}$ with a and the yields of the products were found to be much higher in sulpholane than in an aqueous medium. ${ }^{6}$ Importantly, the hydrolysis of acrylate and its excess usage was avoided by employing these reaction conditions.

Being a poor Michael acceptor, acrylamide (d) has not undergone Baylis-Hillman reaction with other aldehydes excepting 1, under the standard base catalyzed reaction conditions in sulpholane. ${ }^{7}$ However, recent conditions employing DABCO in aqueous conditions ${ }^{6}$ or protic solvent $(\mathrm{MeOH})$ under the influence of microwave ${ }^{13}$ or novel base ${ }^{14}$ resulted in moderate to high yields of adducts, but only with select aldehydes. Since $N$-methylmorpholine is commercially used as a solvent apart from other uses, ${ }^{11}$ reaction of acrylamide with aldehydes $(2,5,7,9-13)$ in $\mathrm{N}$-methylmorpholine as solvent catalyzed by standard base (DABCO) at room temperature is conceived as an attractive proposition. NMM is used since it is expected to: 1) increase the basicity of the reaction medium thus augmenting efficiency of DABCO for a facile Michael addition onto acryl amide and 2) enhance the intermolecular charge-dipole interactions between solvent (itself) and 'Zwitterion', stabilizing the intermediate. Expectedly, the present conditions were found to be congenial not only for reactive aldehydes but also to less reactive aldehydes like benzaldehyde 2, hexanal 7, formaldehyde $\mathbf{1 1}$ and Garner's aldehyde $\mathbf{1 2 .}$

Initially, the Baylis-Hillman reaction between 4-nitrobenzaldehyde $\mathbf{1}$ and acrylamide $\mathbf{d}$ in $\mathrm{N}$ methylmorpholine was carried out in the presence of DABCO (100 mol\%) to give the adduct 1d in $68 \%$ yield. In a further study to ascertain the utility of NMM as a solvent for Baylis-Hillman reactions, a variety of aryl aldehydes such as benzaldehyde 2, 4-chlorobenzaldehyde 9 and 2- 
furfuraldehyde $\mathbf{1 0}$ were subjected to reaction with acrylamide at room temperature to furnish the corresponding adducts 2d, 9d and 10d in good yields (57-63\%).

The versatility of NMM as a solvent for Baylis-Hillman reaction of acrylamide was further demonstrated when a variety of less reactive aldehydes such as hexanal 7, and formaldehyde 11, were successfully made to react with acrylamide at room temperature to give the adducts $\mathbf{7 d}$, 11d, respectively in moderate yields (40-59\%). It is noteworthy to mention that chiral aldehyde 12 reacted with acrylamide in NMM to give the adduct 12d for the first time in 55\% yield (de 30\%). 4-Chlorobenzaldehyde 9 (entry 27, Table 2) and (R)-glyceraldehyde 13 (entry 32, Table 2), apart from 4-nitrobenzalaldehyde $\mathbf{1}$, underwent coupling reaction with ethyl acrylate a under these reaction conditions.

In conclusion, commercially available aprotic polar organic solvents are introduced as alternate solvents for the facile Baylis-Hillman reaction catalyzed by the standard base in order to widen the scope of this reaction towards all kinds of aldehydes and alkenes including acrylamide, a hitherto less preferred Michael acceptor, which underwent Baylis-Hillman reaction with various aldehydes in organic solvent for the first time (See Table 2). Thus, the present reaction conditions are amenable for easy scale up, chance for solvent recovery and wide application; since 1) the substrate scope is widened, as many of the aldehydes and alkenes are compatible when run in these solvents, 2) accelerated reaction rates achieved and 3) in better yields. 
Table 2. Baylis-Hillman reactions of aldehydes with activated alkenes in different solvents at $\mathrm{RT}^{\mathrm{a}, \mathrm{b}}$

\begin{tabular}{|c|c|c|c|c|c|c|}
\hline \multirow{2}{*}{ Entry } & \multirow[t]{2}{*}{ Aldehyde } & \multirow{2}{*}{$\begin{array}{l}\text { Activated } \\
\text { alkene }\end{array}$} & \multirow[t]{2}{*}{ Product } & \multicolumn{3}{|c|}{ Method $^{c}$} \\
\hline & & & & $\mathrm{A}(\%)$ & $\mathrm{B}(\%)$ & $\mathrm{C}(\%)$ \\
\hline 1 & 1 & $\mathbf{a}$ & $1 a$ & $2 \mathrm{~h}(96)$ & $4 \mathrm{~h}(90)$ & $4 \mathrm{~h}(91)$ \\
\hline 2 & 1 & b & $1 b$ & $3 \mathrm{~h}(71)$ & - & - \\
\hline 3 & 1 & c & 1c & $0.5 \mathrm{~h}(91)$ & 1.5 h (90) & - \\
\hline 4 & 1 & d & 1d & $10 \mathrm{~h}(84)$ & - & $10 \mathrm{~h}(68)$ \\
\hline 5 & 1 & e & $1 e$ & $0.75 \mathrm{~h}(76,40 \%$ de & e) - & - \\
\hline 6 & 1 & f & 1f & - & $5 \mathrm{~h}(56)$ & - \\
\hline 7 & 2 & $\mathbf{a}$ & $2 a$ & $6 \mathrm{~h}(86)$ & 12 h (86) & - \\
\hline 8 & 2 & b & $2 \mathbf{b}$ & $1.5 \mathrm{~h}(70)$ & - & - \\
\hline 9 & 2 & c & $2 c$ & 4 h (81) & $8 \mathrm{~h}(83)$ & - \\
\hline 10 & 2 & d & 2d & $\underline{-}$ & - & $13 \mathrm{~h}(57)$ \\
\hline 11 & 2 & $\mathbf{f}$ & $2 f$ & - & $24 \mathrm{~h}(80)$ & \\
\hline 12 & 3 & $\mathbf{a}$ & 3a & $4.5 \mathrm{~h}(93)$ & $6 \mathrm{~h}(82)$ & - \\
\hline 13 & 4 & a & $4 a$ & $10 \mathrm{~h}(85)$ & 8 h (76) & - \\
\hline 14 & 5 & $\mathbf{a}$ & $5 a$ & $6 \mathrm{~h}(73)$ & $10 \mathrm{~h}(79)$ & - \\
\hline 15 & 5 & $\mathbf{b}$ & $5 b$ & $0.75 \mathrm{~h}(75)$ & - & \\
\hline 16 & 5 & c & $5 c$ & $7 \mathrm{~h}(73)$ & $8 \mathrm{~h}(65)$ & - \\
\hline 17 & 5 & d & $5 d$ & - & - & $10 \mathrm{~h}(62)$ \\
\hline 18 & 5 & f & $5 f$ & - & $24 \mathrm{~h}(80)$ & - \\
\hline 19 & 6 & $\mathbf{a}$ & $6 \mathbf{a}$ & $1 \mathrm{~h}(69)$ & $\square$ & 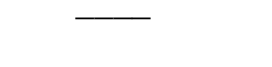 \\
\hline 20 & 6 & b & $6 b$ & $1 \mathrm{~h}(74)$ & $\overline{1}$ & $\bar{\tau}$ \\
\hline 21 & 7 & $\mathbf{a}$ & $7 a$ & $4 \mathrm{~h}(86)$ & $6 \mathrm{~h}(66)$ & $\overline{ }$ \\
\hline 22 & 7 & b & $7 \mathbf{b}$ & $1 \mathrm{~h}(66)$ & 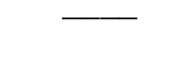 & - \\
\hline 23 & 7 & c & 7c & $8 \mathrm{~h}(72)$ & - & $\overline{15 \mathrm{~h}(50)}$ \\
\hline 24 & 7 & d & $7 d$ & - & - & 15 h (59) \\
\hline 25 & 8 & $\mathbf{a}$ & $\mathbf{8 a}$ & $3 \mathrm{~h}(92,60 \% d$ & - & $\longrightarrow$ \\
\hline 26 & 8 & $\mathbf{b}$ & $\mathbf{8 b}$ & $2 \mathrm{~h}(85,60 \% d$ & - & - \\
\hline 27 & 9 & $\mathbf{a}$ & $9 a$ & - & - & 24 h (76) \\
\hline 28 & 9 & d & 9d & $\longrightarrow$ & $\longrightarrow$ & $12 \mathrm{~h}(54)$ \\
\hline 29 & 10 & d & 10d & & & $12.5 \mathrm{~h}(63)$ \\
\hline 30 & 11 & d & 11d & - & $\overline{-}$ & $14 \mathrm{~h}(40)$ \\
\hline 31 & 12 & d & 12d & & & $12 \mathrm{~h}(55,30 \% \mathrm{de})$ \\
\hline 32 & 13 & $\mathbf{a}$ & $13 a$ & $\longrightarrow$ & - & $24 \mathrm{~h}(65,60 \% \mathrm{de})$ \\
\hline
\end{tabular}

a All the reaction were carried out with aldehyde $(1 \mathrm{mmol})$, activated alkene $(1.5 \mathrm{mmol})$, DABCO (0.5-1.0 mmol) at ambient temperature for 0.5-24 h.

${ }^{\mathrm{b}}$ All the products were characterized by $1 \mathrm{H}$ NMR and other spectral data.

${ }^{\mathrm{c}}$ Yields of isolated products. 


\section{Experimental Section}

General Procedures. Solvents were dried over standard drying agents and freshly distilled prior to use. ${ }^{1} \mathrm{H}-\mathrm{NMR}\left(200 \mathrm{MHz}\right.$ and $300 \mathrm{MHz}$ ) and ${ }^{13} \mathrm{C}-\mathrm{NMR}(50 \mathrm{MHz}$ and $75 \mathrm{MHz})$ spectra were measured with a Varian Gemini FT-200 MHz spectrometer, Bruker-Avance $300 \mathrm{MHz}$ with tetramethylsilane as internal standard for solutions in deuteriochloroform. $J$ values are given in Hz. IR spectra were recorded on Perkin Elmer IR-683 spectrophotometer with $\mathrm{NaCl}$ optics Mass spectra were recorded on CEC-21-11013 or Finnigan Mat 1210 double focusing mass spectrometers operating at a direct inlet system. Organic solutions were dried over anhydrous $\mathrm{Na}_{2} \mathrm{SO}_{4}$ and concentrated below $40{ }^{\circ} \mathrm{C}$ in vacuo.

\section{General experimental procedures}

Method A. To a stirred solution of aldehyde $(1 \mathrm{mmol})$ in sulpholane $(1 \mathrm{~mL})$ were added DABCO $(0.5 \mathrm{mmol})$ and the alkene $(1.5 \mathrm{mmol})$ and the reaction mixture stirred for 0.5 to $10 \mathrm{~h}$ at room temperature. Then the reaction mixture was diluted with water $(20 \mathrm{~mL})$ and extracted with diethylether $(3 \times 10 \mathrm{~mL})$. The combined organic layers were washed with brine, dried $\left(\mathrm{Na}_{2} \mathrm{SO}_{4}\right)$ and concentrated under reduced pressure. The residues thus obtained were purified by column chromatography (silica gel, 60-120 mesh, EtOAc:hexane, 1.5:8) to afford adducts 1a-1e, 2a-2c, 3a, 4a, 5a-c, 6a-b, 7a-c, 8a and $\mathbf{8 b}$ in $66-96 \%$ yields.

Method B. To a stirred solution of aldehyde $(1 \mathrm{mmol})$ in 1-methyl-2-pyrrolidinone (NMP, 1 $\mathrm{mL})$ were added alkene $(1.5 \mathrm{mmol}), \mathrm{DABCO}(0.5 \mathrm{mmol})$ and the reaction mixture stirred for 1 hour to $24 \mathrm{~h}$ at room temperature. Then the reaction mixture was diluted with water $(20 \mathrm{~mL})$ and extracted with ethyl acetate $(3 \times 10 \mathrm{~mL})$. The combined organic layers were washed with brine, dried $\left(\mathrm{NaSO}_{4}\right)$ and concentrated under reduced pressure. The residues were purified by column chromatography (silica gel, 60-120 mesh, EtOAc:hexane, 2:8) to afford adducts 1a, 1c, 1f, 2a, 2c, 2f, 3a, 4a, 5a, 5c, $5 f$ and 7 a in $56-90 \%$ yields.

Method C. To the solution of aldehyde (1 mmol) in NMM (1 mL), DABCO $(1 \mathrm{mmol})$ and alkene (1.5 mmol, ethylacrylate or acrylamide) were added and the reaction mixture stirred for $10-15 \mathrm{~h}$ at room temperature. Then the reaction mixture was partitioned between ethyl acetate (3 x $15 \mathrm{~mL})$ and water $(15 \mathrm{~mL})$, the collected organic layer was washed with brine $(15 \mathrm{~mL})$, dried $\left(\mathrm{Na}_{2} \mathrm{SO}_{4}\right)$ and concentrated under reduced pressure. The residues purified by column chromatography (silica gel, 60-120 mesh, EtOAc:hexane, 2:8-4:6) to afford adducts 1a, 1d, 2d, 5d, 7d, 9a, 9d-12d and 13a in 40-68\% yields.

The compounds were characterized by IR, ${ }^{1} \mathrm{H}$ NMR, mass and other spectral data.

1a. Reference 9a and 9e.

1b. Yellow oil; IR (neat): $v 3418,1713,16191519 \mathrm{~cm}^{-1}$.

${ }^{1} \mathrm{H}$ NMR (300 MHz, CDCl 3 , TMS): $\delta 8.20$ (d, $\left.2 \mathrm{H}, J=8.7 \mathrm{~Hz}, \mathrm{Ar}-\mathrm{H}\right), 7.54(\mathrm{~d}, 2 \mathrm{H}, J=8.3 \mathrm{~Hz}$, Ar-H), 6.66 (s, 1H, olefinic), 6.23 (s, 1H, olefinic), 5.98 (s, 1H, benzylic), 3.12 (d, 1H, $J=5.6$ $\mathrm{Hz},-\mathrm{OH}), 2.32\left(\mathrm{~s}, 3 \mathrm{H},-\mathrm{CH}_{3}\right)$. 
${ }^{13} \mathrm{C}$ NMR (50 MHz, $\mathrm{CDCl}_{3}$, TMS): $\delta 26.3,29.6,72.1,123.5,123.7,127.2,127.7,147.3,148.9$, 200.0 .

EIMS: m/z: $204\left(\mathrm{M}^{+}-17\right)$.

Anal. calcd. for $\mathrm{C}_{11} \mathrm{H}_{11} \mathrm{NO}_{4}$ : C, 59.73; H, 5.01; found: C, 59.57; H, 5.06 .

1c. Yellow oil; IR (neat): $v 3440,2228,1607 \mathrm{~cm}^{-1}$.

${ }^{1} \mathrm{H}$ NMR (200 MHz, $\mathrm{CDCl}_{3}$, TMS): $\delta 8.24$ (d, 2H, $\left.J=8.7 \mathrm{~Hz}, \mathrm{Ar}-\mathrm{H}\right), 7.63(\mathrm{~d}, 2 \mathrm{H}, J=8.4 \mathrm{~Hz}$, Ar-H), 6.39 (s, 1H, olefinic), 6.20 (s, 1H, olefinic), 6.02 (s, 1H, benzylic), 5.38 (br. s, $1 \mathrm{H},-\mathrm{OH})$.

${ }^{13} \mathrm{C}$ NMR (50 MHz, $\mathrm{CDCl}_{3}$, TMS): $\delta 72.1,123.2,126.1,127.2,130.6,147.1,147.8$.

1d. Yellow oil: IR (neat): $v 3540,3341,1694,1621 \mathrm{~cm}^{-1}$.

${ }^{1} \mathrm{H}$ NMR $\left(200 \mathrm{MHz}, \mathrm{CDCl}_{3}\right.$, TMS): $\delta 8.20(\mathrm{~d}, J=8.7 \mathrm{~Hz}, 2 \mathrm{H}, \mathrm{ArH}), 7.54(\mathrm{~d}, J=8.4 \mathrm{~Hz} 2 \mathrm{H}$, ArH), 7.0 (br. s, $1 \mathrm{H}, \mathrm{NH}$ ), 6.0 (br. s, $1 \mathrm{H}$, olefinic), 5.78 (br. s, $1 \mathrm{H}$, olefinic), 5.70 (d, $J=5.6 \mathrm{~Hz}$, $1 \mathrm{H}$, benzylic), 5.60 (s, 1H, NH), 3.41 (br. s, $1 \mathrm{H}, \mathrm{OH})$.

${ }^{13} \mathrm{C}$ NMR (50 MHz, $\mathrm{CDCl}_{3}$, TMS): $\delta$ 71.2, 119.2, 122.4, 122.5, 127.0, 145.3, 149.3, 169.9.

EIMS m/z: $246\left(\mathrm{M}^{+}-1\right)$.

Anal. calcd. for $\mathrm{C}_{13} \mathrm{H}_{13} \mathrm{NO}_{4}$ : C, 63.15, H, 5.30; found: C, 63.21; H, 5.28.

1e. Reference 9a.

1f. Reference 9e.

2a, 2b, 2c. Reference 3.

2d. Reference 14.

2f. Reference 15 .

3a. Colorless oil; IR (neat): $v$ 3396, 1720, $1614 \mathrm{~cm}^{-1}$.

${ }^{1} \mathrm{H}$ NMR (200 MHz, CDCl 3 , TMS): $\delta 7.2$ (br. s, 4H, Ar-H), 6.28 (s, $1 \mathrm{H}$, olefinic), 5.92 (s, $1 \mathrm{H}$, olefinic), 5.52 (d, $1 \mathrm{H}, J=3.7 \mathrm{~Hz}$, benzylic), 4.22 (q, $\left.2 \mathrm{H}, J=7.4 \mathrm{~Hz},-\mathrm{CH}_{2}\right), 3.25$ (d, $1 \mathrm{H}, J=3.7$ $\mathrm{Hz},-\mathrm{OH}), 1.28$ (t, 3H, $\left.J=7.4 \mathrm{~Hz},-\mathrm{CH}_{3}\right)$.

EIMS: $m / z: 241\left(\mathrm{M}^{+}+1\right)$.

Anal. calcd. for $\mathrm{C}_{12} \mathrm{H}_{13} \mathrm{ClO}_{3}$ : C, 59.88; H, 5.44; found: C, 59.71; H, 5.40 .

4a. Reference 3.

5a. Colorless oil; IR (neat): $v$ 3387, $1722,1638 \mathrm{~cm}^{-1}$.

${ }^{1} \mathrm{H}$ NMR (300 MHz, $\mathrm{CDCl}_{3}$, TMS): $\delta$ 8.43-8.39 (m, 2H, ArH), 7.71 (d, $\left.1 \mathrm{H}, J=7.8 \mathrm{~Hz}, \mathrm{ArH}\right)$, 7.24-7.20 (m, 1H, ArH), 6.34 (s, 1H, olefinic), 5.92 (s, 1H, olefinic), 5.55 (s, 1H, benzylic), 4.18 (q, $\left.2 \mathrm{H}, J=6.9 \mathrm{~Hz},-\mathrm{CH}_{2}\right), 1.23\left(\mathrm{t}, 3 \mathrm{H}, J=6.9 \mathrm{~Hz},-\mathrm{CH}_{3}\right)$.

${ }^{13} \mathrm{C}$ NMR (75 MHz, $\left.\mathrm{CDCl}_{3}, \mathrm{TMS}\right): \delta 23.1,51.6,74.5,117.6,126.6,126.7,129.0,130.6,140.1$. EIMS m/z: $207\left(\mathrm{M}^{+}\right)$.

Anal. calcd. for $\mathrm{C}_{11} \mathrm{H}_{13} \mathrm{NO}_{3}$ : C, 63.76; H, 6.32; found: C, 63.65; H, 6.29.

5b, 5c. Reference 3.

5d. Reference 12.

5f. Colorless oil. IR (neat): $v 3441,1694 \mathrm{~cm}^{-1}$.

${ }^{1} \mathrm{H}$ NMR: (300 MHz, $\mathrm{CDCl}_{3}$, TMS): $\delta 8.43-8.39(\mathrm{~m}, 2 \mathrm{H}, \mathrm{Ar}-\mathrm{H}), 7.71(\mathrm{~d}, 1 \mathrm{H}, J=7.7 \mathrm{~Hz}, \mathrm{Ar}-\mathrm{H})$, 7.24-7.20 (m, 1H, Ar-H), $6.82(\mathrm{t}, J=7.1 \mathrm{~Hz}, 1 \mathrm{H}$, olefinic), 5.6 (d, $J=4.8 \mathrm{~Hz}, 1 \mathrm{H}$, benzylic) 3.5 (br. s, 1H, OH), 2.48-2.42 (m, 4H). 
EI Mass m/z: $202\left(\mathrm{M}^{+}-1\right)$.

6a, 6b. Reference 9c.

7a. Colorless oil; IR (neat): $v 3385,1717,1628 \mathrm{~cm}^{-1}$.

${ }^{1} \mathrm{H}$ NMR (300 MHz, $\mathrm{CDCl}_{3}$, TMS): $\delta 6.22$ (s, 1H, olefinic), 5.79 (s, 1H, olefinic), 4.40 (t, $1 \mathrm{H}, J$ $=6.4 \mathrm{~Hz}$, allylic), 4.24 (q, $\left.2 \mathrm{H}, J=7.2 \mathrm{~Hz},-\mathrm{CH}_{2}\right), 2.73$ (br. s, $\left.1 \mathrm{H},-\mathrm{OH}\right), 1.70-1.62\left(\mathrm{~m}, 2 \mathrm{H},-\mathrm{CH}_{2}\right)$, 1.39-1.25 (m, 9H), 0.93-0.84 (m, 3H, $\left.-\mathrm{CH}_{3}\right)$.

${ }^{13} \mathrm{C}$ NMR (75 MHz, $\mathrm{CDCl}_{3}$, TMS): $\delta 12.1,19.5,23.3,29.6,33.4,58.7,69.2,122.9,141.1,164.0$. EIMS $m / z 201\left(\mathrm{M}^{+}+1\right)$.

Anal. calcd. for $\mathrm{C}_{11} \mathrm{H}_{20} \mathrm{O}_{3}$ : C, 65.97; $\mathrm{H}, 10.07$; found: $\mathrm{C}, 65.83 ; \mathrm{H}, 10.02$.

7b, 7c. Reference 3.

7d. Colorless syrup; IR (neat): $v$ 3285, 3190, 1686, $1600 \mathrm{~cm}^{-1}$.

${ }^{1} \mathrm{H}$ NMR (200 MHz, $\mathrm{CDCl}_{3}$, TMS): $\delta 6.4\left(\mathrm{~d}, 1 \mathrm{H}, J=7.6 \mathrm{~Hz}\right.$, olefinic), $6.12-5.93\left(\mathrm{~m}, 2 \mathrm{H}, \mathrm{NH}_{2}\right)$, 5.75 (d, 1H, $J=7.2 \mathrm{~Hz}$, olefinic), 5.45-5.21 (m, 1H, allylic), 1.71-1.16 (m, 8H, $\left.4 \mathrm{x}-\mathrm{CH}_{2}\right), 0.85$ (br. t, $3 \mathrm{H}, \mathrm{CH}_{3}$ ),

EIMS: m/z $154\left[\mathrm{M}^{+}-\mathrm{OH}\right]$.

Anal. calcd. for $\mathrm{C}_{9} \mathrm{H}_{17} \mathrm{NO}_{2}$ : C, 62.13, $\mathrm{H}, 10.01$; found $\mathrm{C}, 63.08, \mathrm{H}, 10.00$.

8a. Reference 9b.

8b. Colorless syrup; IR (neat): $v$ 3428, $1715,1626 \mathrm{~cm}^{-1}$.

${ }^{1} \mathrm{H}$ NMR (300 MHz, $\mathrm{CDCl}_{3}, \mathrm{TMS}$ ): $\delta 6.29$ (s, 0.2H, olefinic), 6.26 (s, 0.8H, olefinic), 6.18 (s, $0.2 \mathrm{H}$, olefinic), 6.11 (s, $0.8 \mathrm{H}$, olefinic), 5.86 (s, $1 \mathrm{H}, J=3.8 \mathrm{~Hz}, \mathrm{H}-1), 4.60-4.48$ (m, 2H, H-5, H2), 4.25-4.17 (m, 1H, H-4), 3.82 (d, 1H, J = 3.7 Hz, H-3), 3.51 (s, 3H, -OMe), 2.41 (s, 3H, $\left.\mathrm{CH}_{3}\right), 1.46\left(\mathrm{~s}, 3 \mathrm{H},-\mathrm{CH}_{3}\right), 1.33\left(\mathrm{~s}, 3 \mathrm{H},-\mathrm{CH}_{3}\right)$.

${ }^{13} \mathrm{C}$ NMR (50 MHz, $\mathrm{CDCl}_{3}$, TMS): $\delta$ 26.7, 57.9, 69.5, 80.2, 81.5, 84.2, 86.5, 105.0, 111.7, 128.0, 147.1, 200.9.

FABMS: $m / z: 273\left(\mathrm{M}^{+}+1\right)$.

Anal. calcd. for $\mathrm{C}_{13} \mathrm{H}_{20} \mathrm{O}_{6}$ : C, 57.34, H, 7.40; found: C, 57.27, H, 7.36.

9a. Colorless oil; ${ }^{1} \mathrm{H}$ NMR (200 MHz, $\mathrm{CDCl}_{3}$, TMS): $\delta 7.30$ (br. s, 4H,Ar-H), 6.30 (br. s, $1 \mathrm{H}$, olefinic), 5.78 (br. s, $1 \mathrm{H}$, olefinic), 5.45 (s, 1H, allylic), 4.17 (q, 2H, J=6.7 Hz, $-\mathrm{CH}_{2}$ ), 3.12 (br. $\mathrm{s}, 1 \mathrm{H},-\mathrm{OH}), 1.31\left(\mathrm{t}, 3 \mathrm{H}, J=6.7 \mathrm{~Hz},-\mathrm{CH}_{3}\right)$.

${ }^{13} \mathrm{C} \mathrm{NMR}\left(50 \mathrm{MHz}, \mathrm{CDCl}_{3}\right.$, TMS): $\delta 166.1,142.1,140.0,133.5,128.4,127.9,125.8,72.6,60.9$, 13.9 .

9d. Colorless syrup; IR (neat): $v 3385,3179,1656,1600 \mathrm{~cm}^{-1}$.

${ }^{1} \mathrm{H}$ NMR (200 MHz, $\mathrm{CDCl}_{3}+$ D6-DMSO, TMS): $\delta$ 7.40-7.20 (m, 4H, Ar-H), 7.19 (br. s, 1H, $\mathrm{NH}), 6.23$ (br. s, $1 \mathrm{H}, \mathrm{NH}), 6.20$ (d, $1 \mathrm{H}, J=4.2 \mathrm{~Hz}$, olefinic), 5.70 (d, $1 \mathrm{H}, J=4.0 \mathrm{~Hz}$, olefinic), 5.43 (s, 1H, allylic).

${ }^{13} \mathrm{C}$ NMR (50 MHz, $\mathrm{CDCl}_{3}+$ D6-DMSO, TMS): $\delta$ 72.4, 121.1, 127.7, 132.4, 140.8, 145.2, 168.8 . EIMS: $\mathrm{m} / \mathrm{z}=210\left[\mathrm{M}^{+}-1\right]$.

Anal. calcd. for $\mathrm{C}_{10} \mathrm{H}_{10} \mathrm{ClNO}_{2}$ : C, 56.75, H, 4.76; found C, 55.91, H, 4.72.

10a. Reference 16.

10d. Reference 14. 
11a. Reference 3 .

11d. Colorless syrup; $1 \mathrm{H}$ NMR $\left(200 \mathrm{MHz}, \mathrm{CDCl}_{3}, \mathrm{TMS}\right): \delta 6.2(\mathrm{~d}, 1 \mathrm{H}), 5.7(\mathrm{~d}, 1 \mathrm{H}), 3.61$ (s, $2 \mathrm{H})$.

EIMS: $101\left[\mathrm{M}-\mathrm{H}_{2} \mathrm{O}\right]$.

12d. Colorless syrup; $[\alpha]_{\mathrm{D}}=-20.0\left(c 0.4, \mathrm{CHCl}_{3}\right) ; 30 \%$ de; IR (neat): $v 3345,3184,1688,1610 \mathrm{~cm}^{-1}$. ${ }^{1} \mathrm{H}$ NMR $\left(200 \mathrm{MHz}, \mathrm{CDCl}_{3}, \mathrm{TMS}\right): \delta$ 6.25-6.05 (m, 1H), 5.95 (br. s, $\left.1 \mathrm{H}\right), 5.64(\mathrm{~s}, 0.65 \mathrm{H}$, allylic), 5.59 (s, 0.35H, allylic), 4.12-3.89 (m, 3H), $1.5\left(\mathrm{~s}, 15 \mathrm{H}, 5 \times \mathrm{CH}_{3}\right)$.

${ }^{13} \mathrm{C} \mathrm{NMR}\left(50 \mathrm{MHz}, \mathrm{CDCl}_{3}, \mathrm{TMS}\right): \delta 23.9,28.3,28.4,59.3,64.9,65.3,94.1,121.0,126.8,131.1$, 167.0.

13a. Reference $9 \mathrm{~g}$.

\section{Acknowledgements}

One of the authors (ERS) thanks CSIR, New Delhi for the support in the form of a fellowship.

\section{References}

\#IICT Communication No. 040807

1. (a) Morita, K. Japan. Patent 68 03, 364, 1968, Chem. Abstr. 1969, 70, 19613u. (b) Baylis, A. B.; Hillman, M. E. D. Ger. Offen. 2,155,113, 1972, Chem. Abstr. 1972, 77, 34174q. (c) Hillman, M. E. D.; Baylis, A. B. U. S. Patent 3743 669, 1973.

2. (a) Basavaiah, D.; Rao, P. D.; Hyma, R. S. Tetrahedron 1996, 52, 8001. (b) Ciganek, E. The Morita-Baylis-Hillman reaction. Org. React. Paquette, L. A. Ed., John Wiley \& Sons, New York, 1997, 51, 201.

3. Basavaiah, D; Rao, A. J.; Satyanarayana, T. Chem. Rev. 2003, 103, 811.

4. Aggarwal, V. K.; Dean, D. K.; Mereu, A.; Williams, R. J. Org. Chem. 2002, 67, 510.

5. Iwabuchi, Y.; Nakatani, M.; Yokoyama, N.; Hatakeyama, S. J. Am. Chem. Soc. 1999, 121, 10219.

6. Yu, C.; Liu, B.; Hu, L. J. Org. Chem. 2001, 66, 5413.

7. Radha Krishna, P.; Manjuvani, A.; Kannan, V.; Sharma, G. V. M. Tetrahedron Lett. 2004, 45, 1183.

8. Lee, K. Y.; Gong, J. H.; Kim, J. N. Bull. Korean Chem. Soc. 2002, 23, 659.

9. (a) Radha Krishna, P.; Kannan, V.; Ilangovan, A.; Sharma, G. V. M. Tetrahedron: Asymmetry 2001, 12, 829. (b) Radha Krishna, P.; Kannan, V.; Sharma, G. V. M.; Ramana Rao, M. H. V. Synlett 2003, 888. (c) Radha Krishna, P.; Raja Sekhar, E.; Kannan, V. Tetrahedron Lett. 2003, 44, 4973. (d) Radha Krishna, P.; Kannan, V.; Sharma, G. V. M. Synth. Comm. 2004, 34, 55. (e) Radha Krishna, P.; Raja Sekhar, E.; Kannan, V. Synthesis 2004, 857. (f) Radha Krishna, P.; Kannan, V.; Narasimha Reddy, P. V. Adv. Synth. Cat. 
2004, 346, 603. (g) Radha Krishna, P.; Narsingam, M.; Kannan, V. Tetrahedron Lett. 2004, $45,4773$.

10. The Merk Index, Published by Merck and Co. Inc., NJ, USA, 1996, Vol. 12, p 6197.

11. (a) Zimmerman, J. E.; Callahan, F. M.; J. Am. Chem. Soc. 1967, 89, 5012. (b) Cox, R. J.; Jenkins, H.; Schouten, J. A.; Stentiford, R. A.; Wareing, K. J. J. Chem. Soc., Perkin Trans 1 2000, 2023. (c) Karpyak, V.V.; Obushak, M. D.; Ganushchak, M. I. Molecules 2003, 8, 263.

(d) The Merk Index, Published by Merck and Co. Inc., NJ, USA, 1996, Vol. 12, p 1075.

12. Yu, C.; Liu, B.; Hu, L. J. Org. Chem. 2002, 67, 219.

13. Kundu, M. K.; Mukherjee, S. B.; Padmakumar, R.; Bhat, S. V. Synlett 1994, 444.

14. Aggarwal, V.; Emme, I.; Fulford, S. H. J. Org. Chem. 2003, 68, 692.

15. Aggarwal, V.K.; Meeru, A, Chem. Commun. 1999, 2311.

16. Cai, J.; Zhou, Z.; Zhao, G.; Tang, C. Org. Lett. 2002, 4, 4723. 